\title{
An investigation on the efficiency of low-cost adsorbents in removing uranium from water samples
}

\author{
Sandeep Police ${ }^{1,2}$. Sukanta Maity ${ }^{1,2}$. Dilip Kumar Chaudhary ${ }^{1}$ Sanjay Kumar Sahu ${ }^{1,2} \cdot$ A. Vinod Kumar ${ }^{1,2}$
}

Received: 16 September 2019 / Accepted: 30 August 2020 / Published online: 11 September 2020

(c) The Author(s) 2020

\begin{abstract}
The groundwater samples were found to be contaminated with high concentrations of uranium (U) in Punjab state as well as in few other locations of India. $U$ being chemically toxic can deteriorate health when ingested. Hence, there is a need to remove $\mathrm{U}$ from contaminated water using an efficient, cheap and user friendly method. A study was initiated to investigate the efficiency of low-cost adsorbents in removing $U$ from water. Seven adsorbents were screened for $U$ removal efficiency, among which fly ash (FA) and tea waste (TW) were found to have better removal efficiency. Solid-liquid contact time and solution $\mathrm{pH}$ were optimized to establish conditions for better $\mathrm{U}$ removal efficiency. The $\mathrm{U}$ adsorption on FA and TW followed pseudo-second-order kinetics with rate constant values $4.63 \mathrm{~g} / \mathrm{mg} / \mathrm{min}$ and $15.63 \mathrm{~g} / \mathrm{mg} / \mathrm{min}$, respectively. FA and TW had the highest $\mathrm{U}$ removal capability at $\mathrm{pH} 6$ and pH 4, respectively. The U sorption data were fitted with Freundlich and Dubinin-Radushkevich isotherm models. The U adsorption on FA and TW is found to be a physical process with mean free energy $(E)$ values less than $8 \mathrm{~kJ} / \mathrm{mol}$. Theoretically calculated maximum adsorption capacity values indicate that FA is a better adsorbent as compared to TW, which has been further confirmed experimentally. The U adsorption on both the adsorbents has interference from $\mathrm{Ca}^{2+}$ and no interference from $\mathrm{Fe}^{3+}$ at tested $\mathrm{U}$ concentrations. It is also found that FA and TW are effective in decontaminating $U$ from spiked real groundwater samples to below the WHO (Guidelines for drinking water quality, 4th ed, vol 1, World Health Organization, Geneva, 2011) limit.
\end{abstract}

Keywords Uranium $\cdot$ Low-cost adsorbents $\cdot$ Batch method $\cdot$ Dubinin-Radushkevich and Freundlich isotherm

\section{Introduction}

Aquatic environmental contamination is currently one of the most important issues faced globally (Idrees et al. 2018; He et al. 2018; Díaz-Cruz and Barceló 2008). Among various contaminants of serious concern, heavy metals such as As, $\mathrm{Se}, \mathrm{Pb}, \mathrm{Cr}, \mathrm{Hg}, \mathrm{Cd}, \mathrm{U}$ are important since they are nonbiodegradable and toxic (Pietrelli et al. 2019; Gupta et al. 2001; El-Bayaa et al. 2009). They can accumulate in living organisms through the ingestion causing various disorders in human and can also have negative impacts on agriculture and aquatic species (Babel et al. 2003a, b; Mishra and Patel

Sanjay Kumar Sahu

sksahu@barc.gov.in

1 Environmental Monitoring and Assessment Division, Health Safety and Environment Group, Bhabha Atomic Research Centre, Mumbai 400085, India

2 Homi Bhabha National Institute, Anushaktinagar, Mumbai 400094, India
2009). Major Indian population depends on groundwater for drinking and irrigation purposes. Hence, it is important to have contamination-free water supply for various applications as mentioned above.

In India, high values of uranium (U) concentrations were recently reported in the ground and surface water samples of Punjab, India (Singh et al. 2013; Bajwa et al. 2017; Pant et al. 2017; Virk 2017). The highest U content in Punjab groundwater has been recorded in the range of $2.1-2.2 \mathrm{mg} / \mathrm{L}$ in 15 habitations of Hoshiarpur district (Virk 2017). The reported $\mathrm{U}$ concentrations are well above the limits prescribed by World Health Organization (WHO 2011; $30 \mu \mathrm{g} / \mathrm{L}$ ) and atomic energy regulatory board (AERB 2004; $60 \mu \mathrm{g} / \mathrm{L}$ ). Also, the drinking water in few other locations of Indian states were found to have $U$ concentration well above the WHO and AERB safety standards (Coyte et al. 2018). U is a long-lived naturally occurring radionuclide present in different environmental matrices and can enter the human body mainly through ingestion resulting in both the chemical and radiological effects (Singh et al. 2013). U predominantly

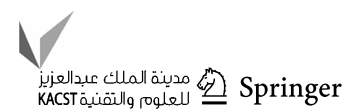


deposits in the kidney, liver and bones causing adverse health effects (Domingo 1995; Sharma et al. 2019). Hence, it is imperative to remove $\mathrm{U}$ from contaminated water.

Different methods such as precipitation, ion exchange, reverse osmosis (RO), electrochemical treatment, evaporation, solvent extraction and biological materials have been used to remove heavy metals, organic contaminants and other unwanted materials from the contaminated water. RO requires a high operating pressure and fouling of membranes limits the process. The solvent extraction and electrolytic processes are economical, but these process are applicable only when the pollutant concentration is high (Wang et al. 2003). With advancement in science, researchers have focused on the synthesis of nano-hybrid cation-exchanger, polymeric hybrid nanocomposite and ion-selective membrane materials for selective separation of toxic metals and other contaminants from aqueous solutions as well as from other media (Khan et al. 2019a, b, c; Eltayeb and Khan 2019; Inamuddin et al. 2017). These materials are proven to be promising in environmental management studies (Khan et al. 2019a, b, c, d). A few processes mentioned above (RO, electrochemical treatment, solvent extraction) are time consuming, high-energy demanding, economically unfavorable and also applicable only for high metals concentrations (Mishra and Patel 2009; Qadeer and Akhtar 2005). Therefore, studies need to be conducted to develop alternative methods that are user friendly, economically feasible and effective at low concentrations as well.

Adsorption is a surface phenomenon in which adsorbate species transfer from the bulk solution to the solid surface. The adsorption can be either physical or chemical adsorption depending on the nature of forces involved in binding the adsorbate on adsorbent. Although various techniques are available for water/wastewater purification, the adsorption process has gained attention in wide range of applications such as pollution control, purification of liquid and gas mixtures due to its high efficiency, reusability, cost effectiveness, simplicity of operation and low sludge production (Anirudhan et al. 2010; Barakat 2011; Fu and Wang 2011). There are large number of studies reported on the removal of $\mathrm{As}, \mathrm{Pb}$, $\mathrm{Cd}, \mathrm{Ni}, \mathrm{Hg}, \mathrm{Zn}, \mathrm{Se}, \mathrm{Cr}$ and other contaminants using various low-cost adsorbents such as fruit peels, rice husk, activated carbon, saw dust, zeolite, fly ash, tea waste, kaolin, bagasse, peat moss, chitin, bentonite, blast furnace slag, apatite, bentonite and industrial waste materials (Dimitrova 1996; Ajmal et al. 2000; Babel and Kurniawan 2003a, b; Babel and Kurniawan 2004; Bishnoi et al. 2003; Onal et al. 2007; Roy et al. 2013; Montes-Atenasa and Schroeder 2015; Tripathi and Ranjan 2015; Jellali et al. 2016; Chen et al. 2017; Khandaker et al. 2018; Mustapha et al. 2019; Calimli et al. 2019; Demirbaş et al. 2019). Some studies reported on U removal from contaminated water using synthetic cost adsorbents (Dimiropoulos et al. 2015; Pang et al. 2019). These synthetic materials are reported to have appreciable affinity for $\mathrm{U}$ with good removal efficiencies; however, material synthesis will increase the cost of the adsorbent as compared to natural adsorbents. The low-cost adsorbents discussed above were found to have excellent adsorption properties for targeted metals with good metal removal capacities. Therefore, it is important to search for a low-cost natural adsorbent for metal decontamination from aqueous solutions.

In the present study, seven adsorbents were examined for their U removal efficiency from U spiked water samples using batch method (Maity et al. 2011; Roy et al. 2013). The screening test was carried out to identify a better adsorbents among the seven adsorbents used in the study. The factors influencing the $\mathrm{U}$ adsorption such as solid-liquid contact time, solution $\mathrm{pH}$, concentration of co-existing cations and initial adsorbate concentration were studied on the selected adsorbents which had better $U$ removal efficiency in screening test. Finally, $U$ decontamination from spiked real groundwater samples was also studied at optimized conditions.

\section{Materials and method}

\section{Adsorbents and initial screening study for $U$ decontamination}

Seven adsorbents [tea waste (TW), teak wood, rice husk, coconut charcoal (CC), bentonite clay (MM), corn cob powder and fly ash (FA)] were used to study the U removal efficiency from water. These materials are chosen since they are cheap and available easily. Teak wood powder was collected from carpenter shop, and FA was collected from thermal power plant. Remaining materials were purchased from local market. TW is washed several times with deionized water to remove coloring material then dried and homogenized.

All experiments have been carried out in triplicate in polypropylene centrifuge tubes which were pre-cleaned with dil. $\mathrm{HNO}_{3}$. One gram of each adsorbent is taken in centrifuge tubes, and $30 \mathrm{~mL}$ of $\mathrm{U}$ spiked deionized water is added to it. The adsorption experiments have been carried out in an orbital shaker with continuous shaking at $120 \mathrm{rpm}$ speed. After each experiment, the supernatant is separated by centrifugation (at 12,000 rpm speed) followed by filtration through $0.45 \mu \mathrm{m}$ filter paper and solutions are analyzed for $\mathrm{U}$ after sample preparation.

In the initial screening test, all the above-mentioned adsorbents were used to estimate their $\mathrm{U}$ removal efficiency by spiking the aqueous solution with known $U$ concentration $(3568 \mu \mathrm{g} / \mathrm{L})$. The admixtures are shaken for $5 \mathrm{~h}$, centrifuged and filtered as discussed above. The filtrate is reduced on hot plate by adding $0.4 \mathrm{~mL}$ concentrated high purity nitric acid, 
and final solution is prepared in standard volumetric flask by giving multiple washings to the sample beaker.

\section{Time variation study and sorption kinetics}

One gram of adsorbent was mixed with $30 \mathrm{~mL}$ of $\mathrm{U}$ spiked $(3568 \mu \mathrm{g} / \mathrm{L}$ ) deionized water (solid/liquid ratio 1:30). The batch experiments were carried out in an orbital shaker for different contact time period varying from $10 \mathrm{~min}$ to $5 \mathrm{~h}$. The supernatant solution is separated by centrifugation and filtration. The resulting solution is acidified, reduced and analyzed for $\mathrm{U}$ using differential pulse adsorptive stripping voltammetry (DPAdSV) technique. The time at which $\mathrm{U}$ concentration in the supernatant becomes constant is accepted as equilibrium time for corresponding adsorbent. Different kinetic models such as pseudo-first-order model (Eq. 1), pseudo-second-order model (Eq. 2) (Ho and McKay 1999) and intra-particle-diffusion model (Eq. 3) are used to fit the time variation study data in order to get the information on the controlling mechanisms of $U$ adsorption. The intra-particle-diffusion model can identify the diffusion mechanism and its kinetics in the adsorption process. If $q_{t}$ versus $t^{0.5}$ plot is linear and passes through the origin then intra-particle diffusion mechanism is the major rate limiting step in the adsorption process (Weber and Morris 1963).

$$
\begin{aligned}
& \log \left(q_{\mathrm{e}}-q_{t}\right)=\log q_{\mathrm{e}}-\left(\frac{K_{1} * t}{2.303}\right) \\
& \frac{t}{q_{t}}=\left(\frac{1}{K_{2} q_{\mathrm{e}}^{2}}\right)+\left(\frac{t}{q_{\mathrm{e}}}\right) \\
& q_{t}=k_{i} t^{1 / 2}+C
\end{aligned}
$$

where $q_{\mathrm{e}}$ and $q_{t}$ are the amount of $\mathrm{U}$ adsorbed $(\mathrm{mg} / \mathrm{g})$ at equilibrium and at time $t(\mathrm{~min})$, respectively, and $k_{1}\left(\mathrm{~min}^{-1}\right)$ is the pseudo-first-order rate constant. The terms $t$ and $K_{2}$ in Eq. 2 represents the time and pseudo-second-order rate constant (min $\mathrm{g} / \mathrm{mg}) . K_{i}\left(\mathrm{mg} / \mathrm{g} / \mathrm{min}^{-0.5}\right)$ and $C$ in Eq. 3 represent the intra-particle diffusion rate constant and the intercept.

\section{Effect of pH on $\mathrm{U}$ adsorption}

Solution $\mathrm{pH}$ is an important parameter that controls the adsorption of $\mathrm{U}$ on the adsorbents (Maity et al. 2013). In the present study, solution $\mathrm{pH}$ was varied from 4 to 9 using dilute $\mathrm{HNO}_{3}$ and $\mathrm{NaOH}$ after spiking the solution with known $\mathrm{U}$ concentration $(1415 \mu \mathrm{g} / \mathrm{L})$. The mixture is shaken for equilibration time and centrifuged to separate the supernatant, which is analyzed for U content using DPAdSV technique.
The point of zero charge (PZC) plays an important role in surface characterization of adsorbent. In the current study, PZC of both the adsorbents are estimated using $50 \mathrm{~mL}$ of $0.01 \mathrm{M} \mathrm{NaCl}$. The $\mathrm{NaCl}$ solutions are adjusted to the different initial $\mathrm{pH}$ values. A $0.1 \mathrm{~g}$ of adsorbent is added to the each solution with different initial $\mathrm{pH}$ values and then shaken for $24 \mathrm{~h}$ (Zyoud et al. 2019). The difference between initial and final $\mathrm{pH}$ values is calculated and the initial $\mathrm{pH}$ where the $\Delta \mathrm{pH}$ becomes zero is considered as PZC of the adsorbent.

\section{Effect of initial $\mathrm{U}$ concentration on adsorption}

Adsorption capacity can change with change in initial adsorbate concentration. Hence, in the present study, experiments were carried out (for equilibration time and at optimized $\mathrm{pH}$ ) by varying the adsorbate concentration from 109 to $7803 \mu \mathrm{g} / \mathrm{L}$. U concentration left in supernatant solution is analyzed for each initial concentration. The change in adsorption with initial $U$ concentration data was fitted with different adsorption isotherm models like Langmuir (Eq. 4), Freundlich (Eq. 5) and Dubinin-Radushkevich (D-R, Eq. 6). The Langmuir model is based on the assumption that the surface is homogeneous and all the adsorption sites have equal affinity for adsorbate. Whereas, Freundlich model assumes that the surface is heterogeneous and adsorption can occur in multilayer (Mishra and Patel 2009; Mohan and Pittman 2006). D-R model is applied to the adsorption mechanism with a Gaussian energy distribution onto a heterogeneous surface can be fitted well when solute concentration is high and in intermediate range.

$\frac{C_{\mathrm{e}}}{q_{\mathrm{e}}}=\frac{1}{Q * b}+\frac{C_{\mathrm{e}}}{Q}$

$\log q_{\mathrm{e}}=\log K_{\mathrm{f}}+\frac{1}{n} \log C_{\mathrm{e}}$

$\ln q_{\mathrm{e}}=\ln q_{\mathrm{m}}-K \varepsilon^{2}$

$\varepsilon=R T \ln \left(1+\frac{1}{C_{\mathrm{e}}}\right)$

The parameters in Eqs. 4, 5 and 6, i.e., $q_{\mathrm{e}}, C_{\mathrm{e}}, Q$ and $q_{\mathrm{m}}$ are the amount of contaminant adsorbed per unit mass of adsorbent $(\mathrm{mg} / \mathrm{g})$ at equilibrium, the equilibrium concentration of contaminant in the bulk solution $(\mathrm{mg} / \mathrm{L})$, the monolayer adsorption capacity $(\mathrm{mg} / \mathrm{g})$ and the theoretical isotherm saturation capacity, respectively. Terms $b$ and $K$ are constants related to the adsorption energy, whereas, $K_{\mathrm{f}}$ and $n^{-1}$ are constants related to adsorption capacity of the adsorbent $(\mathrm{mg} / \mathrm{g})$ and the intensity of the adsorption, 
respectively. $R$ is the universal gas constant $(\mathrm{J} / \mathrm{mol} / \mathrm{K})$ and $T$ is the temperature in Kelvin.

The mean free energy of adsorption $(E)$ was calculated from the constant $K$ using the relation given by Namasivayam and Yamuna (1995).

$E=(2 K)^{-1 / 2}$

\section{Co-existing cation's concentration effect on $\mathrm{U}$ adsorption}

Major multivalent cations (such as $\mathrm{Ca}^{2+}, \mathrm{Mg}^{2+}$ and $\mathrm{Fe}^{3+}$ ) in water can interfere with $\mathrm{U}$ for adsorption on adsorbent material. The typical concentration of $\mathrm{Ca}^{2+}, \mathrm{Mg}^{2+}$ and $\mathrm{Fe}^{3+}$ in water samples is reported in the range of $28-209 \mathrm{mg} / \mathrm{L}$, 4-75 $\mathrm{mg} / \mathrm{L}$ and $0.2-0.7 \mathrm{mg} / \mathrm{L}$, respectively (Bajwa et al. 2017). To study the interference effect from these cations on $\mathrm{U}$ adsorption, the added concentration of $\mathrm{Ca}^{2+}$ and $\mathrm{Mg}^{2+}$ was varied from 50 to $400 \mathrm{mg} / \mathrm{L}$, whereas $\mathrm{Fe}^{3+}$ concentration was varied from 1 to $20 \mathrm{mg} / \mathrm{L}$. All the solutions were prepared from their corresponding chloride salts (i.e., $\mathrm{MgCl}_{2} \cdot 6 \mathrm{H}_{2} \mathrm{O}$, $\mathrm{CaCl}_{2}$ and $\mathrm{FeCl}_{3}$ ) using deionized water $(18 \mathrm{M} / \mathrm{cm})$. During the experiment, the spiked $\mathrm{U}$ concentration $(1415 \mu \mathrm{g} / \mathrm{L})$ was kept constant.

In the present study, surface morphology and major functional groups of adsorbents are studied using scanning electron microscope (SEM, EMCRAFTS make, CUBE 100 model) and Fourier-transform infrared spectroscopy (FTIR, Bruker make ALPHA II model) to understand the role of surface structure and functional groups on $\mathrm{U}$ adsorption.

\section{Chemical reagents}

High purity $\mathrm{HNO}_{3}$ from Merck is used in the present study for volume reduction process as well as to adjust solution pH. Other chemicals (viz. $\mathrm{MgCl}_{2} \cdot 6 \mathrm{H}_{2} \mathrm{O}, \mathrm{CaCl}_{2}$ and $\mathrm{FeCl}_{3}$, Chloranilic acid and EDTA) used in the present study are of analytical grade purity and are purchased from SigmaAldrich and Merck. Deionized water $(18 \mathrm{M} \Omega / \mathrm{cm})$ is used for dilution of standards, samples and chemical compounds.

\section{Analytical method}

In the present study, $\mathrm{U}$ analysis has been carried out using DPAdSV technique in metrohm make voltammetry system (663 VA stand, PGSTAT-AUTOLAB-302N.220AUT84360 model). The system equipped with three electrodes viz. hanging mercury drop, $\mathrm{Ag} / \mathrm{AgCl}$ electrode and platinum ( $\mathrm{Pt}$ ) electrode. $\mathrm{Hg}$ drop and $\mathrm{Ag} / \mathrm{AgCl}$ electrode act as working electrode and reference electrode, whereas $\mathrm{Pt}$ rod acts as auxiliary electrode. Required amount of sample solution is taken in measuring cell, to that chloranilic

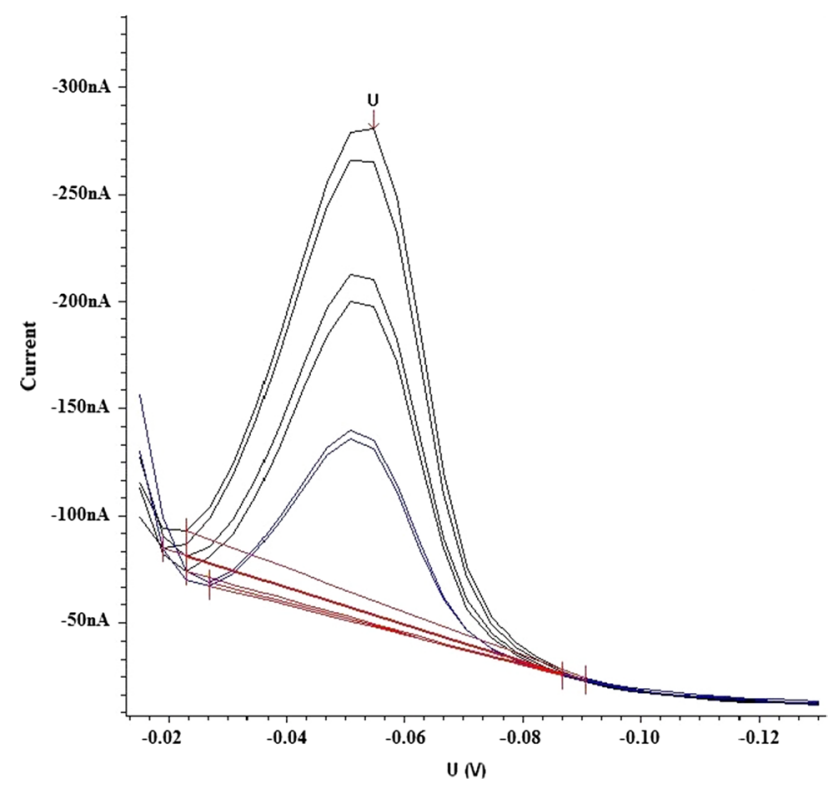

Fig. $1 \mathrm{U}$ peak ( $y$-axis current in $\mathrm{nA} ; x$-axis voltage) in sample solution observed through standard addition method

Table 1 DPAdSV method parameters optimized for U analysis

\begin{tabular}{llll}
\hline Parameters & Value & Parameters & Value \\
\hline Initial purging time (s) & 120 & Pulse amplitude (mV) & 50 \\
Deposition time (s) & 90 & Pulse time (s) & 0.04 \\
Equilibration time (s) & 9 & Voltage step time (s) & 0.4 \\
Deposition potential (V) & 0.08 & Sweep rate (mV/s) & 9.9 \\
End potential (V) & -0.15 & No. of standard additions & 2 Nos. \\
\hline
\end{tabular}

acid, ethylenediaminetetraacetic acid (EDTA) and deionized water are added to make total cell volume $10 \mathrm{~mL}$. The mixture is adjusted for $\mathrm{pH}$ in the range of 1.9-2.1 using dilute $\mathrm{HNO}_{3}$ and $\mathrm{NaOH}$. Then, the mixture is purged with high purity $\mathrm{N}_{2}$ gas and analyzed for $\mathrm{U}$ content by standard addition method using freshly prepared $\mathrm{U}$ standard solution (makeup in deionized water). The typical voltammogram of the sample and detailed method parameters are presented in Fig. 1 and Table 1, respectively.

\section{Results and discussion}

\section{Initial screening test results}

The $\mathrm{U}$ concentration remained in supernatant solution after adsorption is shown in Table 2. It was observed that, TW and FA had better U removal efficiency (w.r.t WHO and AERB limits) as compared to other adsorbents. Therefore, further studies are carried out only on these two adsorbents. 
Table 2 U concentration remained in supernatant after adsorption process

\begin{tabular}{llll}
\hline Adsorbents & $\begin{array}{l}\text { Added U concentration } \\
(\mu \mathrm{g} / \mathrm{L})\end{array}$ & $\begin{array}{l}\text { U concentration }(\mu \mathrm{g} / \mathrm{L}) \\
\text { remained in solution }\end{array}$ & $\begin{array}{l}\text { Removal } \\
\text { efficiency } \\
(\%)\end{array}$ \\
\hline CC modified (using KOH) & 3568 & 379.1 & 89.4 \\
MM & 3568 & 137.4 & 96.1 \\
Corn Cob & 3568 & 101.3 & 97.2 \\
Rice Husk & 3568 & 163.7 & 95.4 \\
Teak Wood & 3568 & 92.5 & 97.4 \\
Tea waste (TW) & 3568 & 60.7 & 98.3 \\
Fly Ash (FA) & 3568 & 35.7 & 99.0 \\
\hline
\end{tabular}

\section{Estimation of adsorption equilibrium time}

Results presented in Fig. 2 suggest that initially there is fast $\mathrm{U}$ uptake on both the adsorbents up to $120 \mathrm{~min}$. After $120 \mathrm{~min}$, the adsorption became slow and eventually reaches plateau region. From Fig. 2, it is clear that the equilibrium is achieved after $210 \mathrm{~min}$ of contact time for FA and after $240 \mathrm{~min}$ for TW. Hence, further experimental studies are carried out using established equilibrium time for respective adsorbent.

\section{Sorption kinetics}

The pseudo-first-order, pseudo-second-order and intraparticle diffusion kinetic models were used to simulate the experimental data by plotting the linear graph between log $\left(q_{\mathrm{e}}-q_{t}\right)$ versus $t,\left(t / q_{t}\right)$ versus $t$, and $q_{t}$ versus $t^{0.5}$, respectively, and compared the regression coefficients for each expression. The $\mathrm{U}$ adsorption data are not satisfied pseudofirst-order rate expression and have lower correlation coefficient. Also, theoretically calculated $q_{\mathrm{e}}$ value is not in agreement with the experimental value. But, the data are well fitted with the pseudo-second-order kinetic model (presented in Fig. 3) for both the adsorbents with $R^{2}$ value of 0.99 . The pseudo-second-order rate constant is calculated from intercept, and the values are found to be $4.48 \mathrm{~g} / \mathrm{mg} /$ $\mathrm{min}$ for FA and $15.63 \mathrm{~g} / \mathrm{mg} / \mathrm{min}$ for TW. The experimental $q_{\mathrm{e}}$ value observed for both the adsorbents is also well matched with the theoretically calculated values from the pseudosecond-order rate model.

The adsorption data are also fitted with the intra-particle diffusion model. As shown in Fig. 4, the plot between $q_{t}$ and $t^{0.5}$ is a multi-linear. This indicates that $\mathrm{U}$ adsorption on FA and TW is a multi-step process. It is clear from Fig. 4 that $\mathrm{U}$ adsorption is rapid during the first $1 \mathrm{~h}$ and then, the adsorption became slow between 60 and $180 \mathrm{~min}$ and then reaches equilibrium after $200 \mathrm{~min}$. Three phases (i.e., sharply linear, linear and plateau) can be seen in both the plots that do not pass through the origin, which indicates that the intra-particle-diffusion is not the only rate-determining step in $\mathrm{U}$ adsorption on FA and TW. The first (sharp linear) portion of the graph represents the diffusion of $U$ through
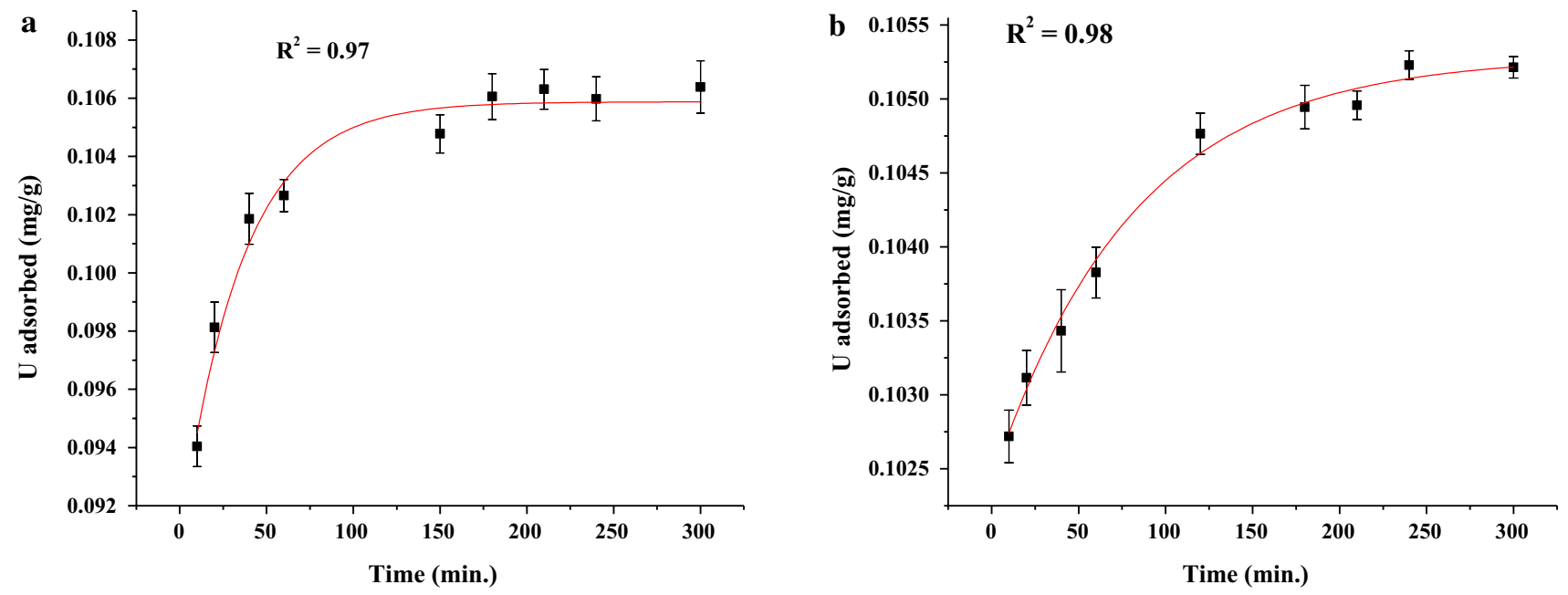

Fig. 2 Variation of $U$ adsorption with respect to solid-liquid contact time for $\mathbf{a}$ FA and $\mathbf{b}$ TW 

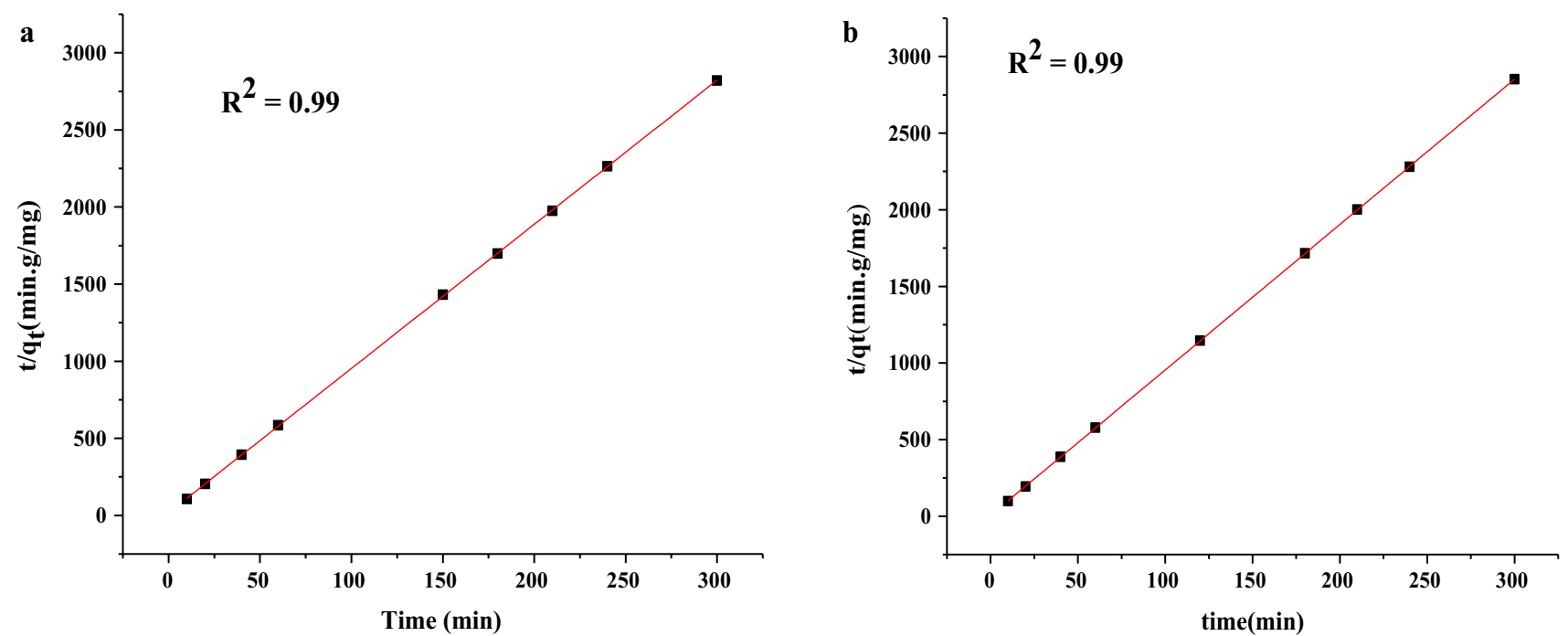

Fig. 3 Plots of pseudo-second-order model for U adsorption using a FA and $\mathbf{b}$ TW
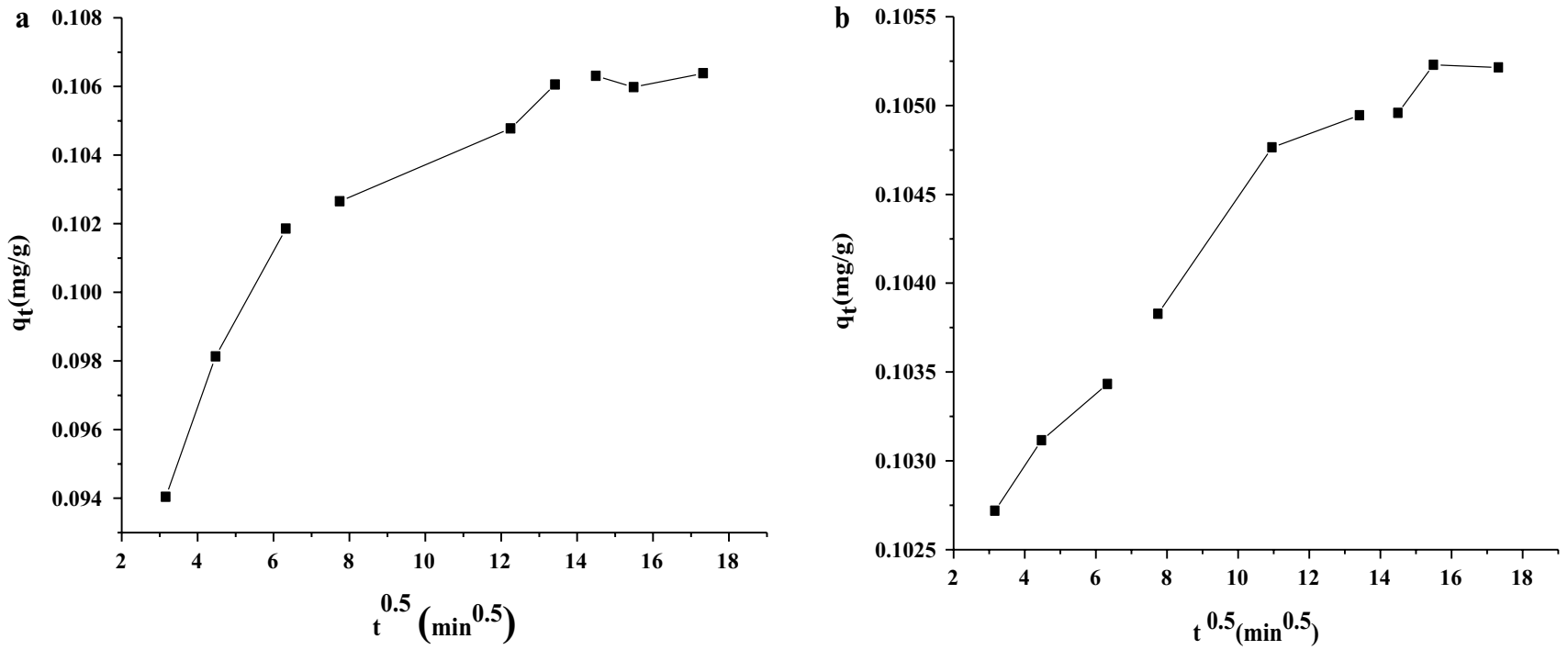

Fig. 4 Intra-particle diffusion model plot for U adsorption on a FA and $\mathbf{b}$ TW

the solution to the external surface of the adsorbents or macro-pore diffusion. The second linear portion describes the gradual adsorption, where intra-particle or micro-pores diffusion is the rate-determining step and the third phase can be attributed to the final equilibrium in which the intraparticle diffusion starts to slow down due to extremely low $\mathrm{U}$ concentration left in the supernatant solution. The intraparticle diffusion constant $\left(K_{i}\right)$ values were obtained from the slope of the straight-line portions of plot of $q_{t}$ versus $t^{0.5}$, and the values are found to be $2 \mathrm{E}-03 \mathrm{mg} / \mathrm{g} / \mathrm{min}^{0.5}$ for FA and $2.4 \mathrm{E}-04 \mathrm{mg} / \mathrm{g} / \mathrm{min}^{0.5}$ for TW. In the present study, the intercept values are observed to be positive for both the adsorbents.

\section{Effect of solution pH}

From Fig. 5, it can be observed that there is a lesser change in percentage $\mathrm{U}$ adsorbed on $\mathrm{TW}$, whereas appreciable change in adsorption is observed in the case of FA over the range of tested $\mathrm{pH}$ values. Results (shown in Fig. 5) indicate that, $\mathrm{U}$ adsorption is low at higher solution $\mathrm{pH}$ values (i.e., from 7 to 9), whereas higher $U$ adsorption is observed at lower $\mathrm{pH}$ (i.e., 4 to 6 ) for both the studied adsorbents. Highest adsorption of $\mathrm{U}$ is found at $\mathrm{pH} 6$ and $\mathrm{pH} 4$ for FA and TW, respectively. The $\mathrm{U}$ concentration left in the supernatant solution at these $\mathrm{pH}$ values is found to be $20.4 \mu \mathrm{g} / \mathrm{L}$ and $31.1 \mu \mathrm{g} / \mathrm{L}$, for FA and TW, respectively. The 

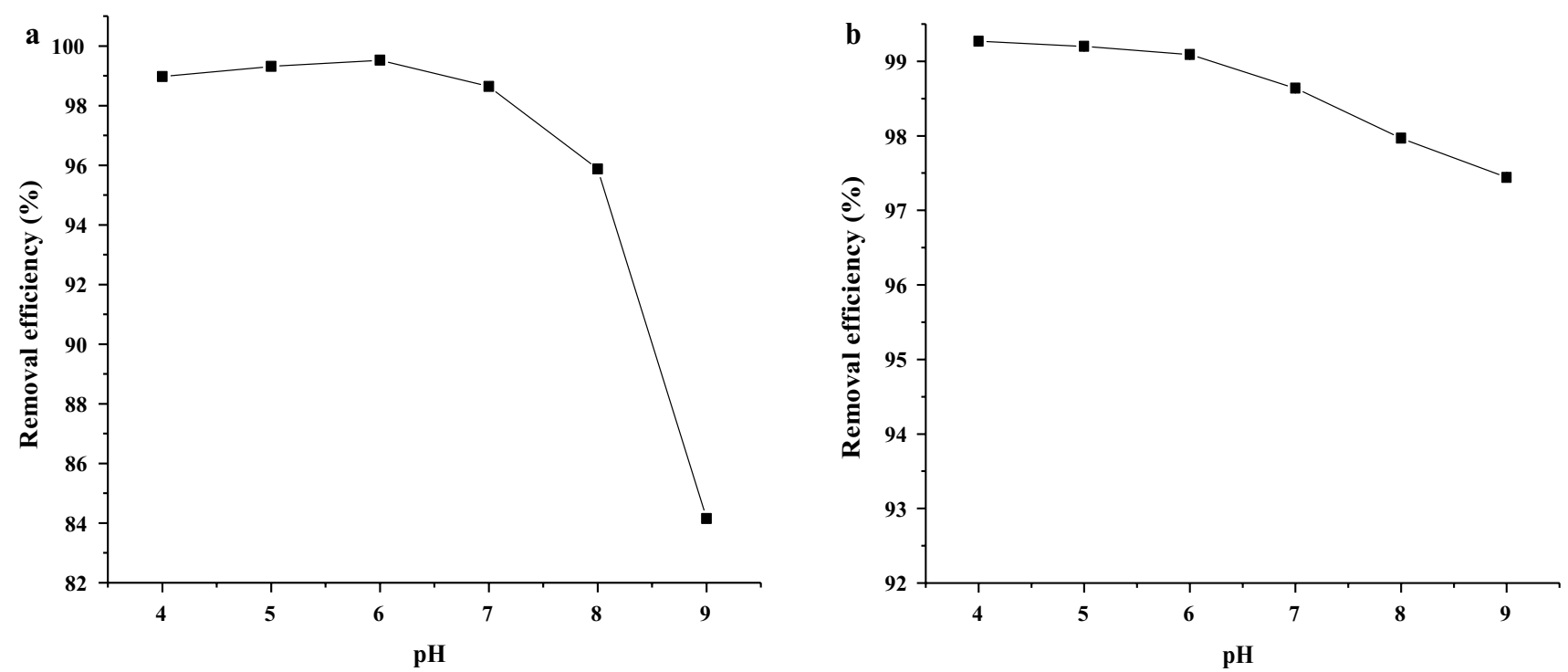

Fig. 5 Variation of $\mathrm{U}$ removal with solution $\mathrm{pH}$ in $\mathbf{a}$ FA and $\mathbf{b} \mathrm{TW}$

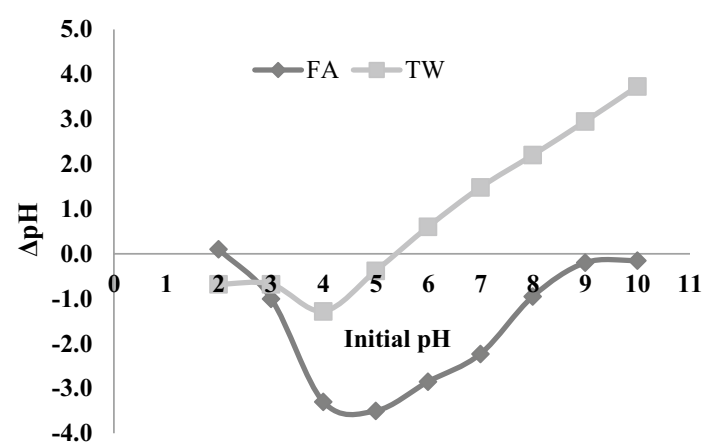

Fig. 6 Variation of $\Delta \mathrm{pH}$ with the change in initial $\mathrm{pH}$ of adsorbentsolution mixture

removal efficiency is found in the range of $84.2-99.5 \%$ and 97.4-99.3\% for FA and TW, respectively over the tested $\mathrm{pH}$ values. Although the highest adsorption of $U$ is observed at $\mathrm{pH} 4$ for TW, further studies are carried out at $\mathrm{pH}$ of 6 for both the adsorbents, as $\mathrm{pH} 6$ is close to the standard $\mathrm{pH}$ for drinking water given by Bureau of Indian Standards (BIS).

The PZC (Fig. 6) of FA and TW are found at $\mathrm{pH} 2.1$ and pH 5.5, respectively. Davis et al. (1978) and Sahoo et al. (2013) also reported the ZPC in the range of 2.2-3.5 for Silica and alumino-silicate minerals. For FA, the surface charges are negative at $\mathrm{pH}>2.1$, whereas for TW surface charges are negative at $\mathrm{pH}>5.5$ and favors the $\mathrm{U}$ adsorption. The lower U uptake at $\mathrm{pH} 4$ for FA could be due to high concentration of $\mathrm{H}^{+}$ions which being smaller in size and highly mobile competes for available adsorption sites leading to decreased $\mathrm{UO}_{2}{ }^{2+}$ adsorption. Also, the ion-exchangeable sites (i.e., iron-oxides, aluminum oxides and natural organic matter) available on adsorbent surface decreases at lower pH (Maity et al. 2011) resulting in poor adsorption. In the case of TW, lower adsorption is not observed at $\mathrm{pH} 4$, which might be found at even lower solution $\mathrm{pH}$ conditions (i.e., less than 4) which was not included in the present study. A slight increase in the $\mathrm{U}$ adsorption at $\mathrm{pH}<5$ on TW indicates that the adsorption is not exclusively due to the electrostatic interactions. As $\mathrm{pH}$ increases (up to $\mathrm{pH}$ 6), the adsorbent surface becomes more negative and the competition from $\mathrm{H}^{+}$ ions decreases which favors the $\mathrm{U}$ adsorption on adsorbent surface. As $\mathrm{pH}$ increases further, there is a drastic decrease in the $\mathrm{U}$ adsorption. At solution $\mathrm{pH} \geq 7$ (i.e., beyond $\mathrm{PZC}$ ), the adsorbent surface becomes more negative and the $\mathrm{U}$ species also form anionic complexes such as $\mathrm{UO}_{2}\left(\mathrm{CO}_{3}\right)_{2}^{2-}$ and $\mathrm{UO}_{2}\left(\mathrm{CO}_{3}\right)_{3}^{4-}$ which faces repulsions from the negatively charged adsorbent surface and does not favors the adsorption (Silva and Nitsche 1995; Echevarria et al. 2001).

\section{Effect of initial $U$ concentration and adsorption isotherms}

The initial U concentration was varied from 109 to $7803 \mu \mathrm{g} / \mathrm{L}$ (solid/liquid-1:30) to investigate the U removal efficiency of adsorbents over wide concentration range maintaining the solution $\mathrm{pH}$ at 6 . Results indicate that, as initial $\mathrm{U}$ concentration increases, the amount of adsorbed $\mathrm{U}$ also increases. But, the percentage removal remains almost constant over the tested concentration range. The U concentration left in the supernatant solutions (shown in Table 3) after adsorption is found to be less than the limits prescribed by WHO (2011) and AERB for all initial U concentrations up to $3568 \mu \mathrm{g} / \mathrm{L}$ and $7803 \mu \mathrm{g} / \mathrm{L}$, respectively in the case of FA.

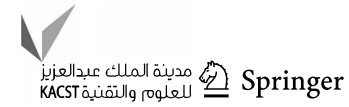


Table $3 \mathrm{U}$ concentration left in supernatant for different $\mathrm{U}$ initial concentrations with $1 \mathrm{~g}$ of $\mathrm{FA}$ and $\mathrm{TW}$ at $\mathrm{pH} 6$

Added $\mathrm{U}$ ini- $\quad \mathrm{U}$ concentration $(\mu \mathrm{g} / \mathrm{L})$ in supernatant solution after tial concentra- adsorption

tion $(\mu \mathrm{g} / \mathrm{L})$

$$
\text { FA }
$$

\% Removal TW

$\%$ Removal

\begin{tabular}{lrrr}
\hline 109.7 & $0.9 \pm 0.04$ & 99.2 & $4.0 \pm 0.1796 .3$ \\
179.5 & $2.7 \pm 0.10$ & 98.5 & $8.9 \pm 0.3595 .1$ \\
691.2 & $8.9 \pm 0.31$ & 98.7 & $21.0 \pm 0.6797 .0$ \\
1415.9 & $11.6 \pm 0.37$ & 99.2 & $35.4 \pm 1.1797 .5$ \\
3568.3 & $28.1 \pm 0.65$ & 99.2 & $84.5 \pm 2.1197 .6$ \\
7803.2 & $36.1 \pm 0.72$ & 99.5 & $103.4 \pm 2.1798 .7$ \\
\hline
\end{tabular}

Whereas, TW was able to reduce the $U$ concentration to less than WHO and AERB limits for initial U concentration only up to $691.2 \mu \mathrm{g} / \mathrm{L}$ and $1415.9 \mu \mathrm{g} / \mathrm{L}$, respectively. From Table 3, it can also be observed that, FA has more removal capacity for $\mathrm{U}$ as compared to TW.

The study data are not well fitted with Langmuir isotherm model (with $\mathrm{R}^{2}$ values 0.35 for FA and 0.63 for TW), indicating that the adsorption is not monolayer. However, the data are well fitted with Freundlich and D-R isotherm models. Thus, it can be said that $\mathrm{U}$ adsorption on these adsorbents is a multilayer processes and the surface of these adsorbents consists of small heterogeneous particles. This observation is also explained in intra-particle-diffusion model. Freundlich constants related to the adsorption capacity $\left(K_{\mathrm{f}}\right)$ and adsorption intensity $(n)$ are calculated from the slope $(1 / n)$ and an intercept $\left(\log K_{\mathrm{f}}\right)$ of plot between $\log \left(q_{\mathrm{e}}\right)$ versus $\log \left(C_{\mathrm{e}}\right)$. The $\mathrm{U}$ adsorption on FA and TW is favorable as the $n$ value (shown in Table 4) is greater than 0.1 . Similarly, the D-R isotherm constants are calculated from the plot between $\operatorname{Ln}\left(q_{\mathrm{e}}\right)$ versus $\varepsilon^{2}$ and are presented in Table 4 . The adsorption energy $(E)$ values are found to be $5.3 \mathrm{~kJ} / \mathrm{mol}$ (for FA) and $4.3 \mathrm{~kJ} / \mathrm{mol}$ (for TW) which being less than $8 \mathrm{~kJ} / \mathrm{mol}$ indicates that $\mathrm{U}$ sorption on both the adsorbents is a physical process, which suggests that the adsorbents can be regenerated for further use through desorption.

In the present study, the reported maximum adsorption capacity results are compared (in Table 5) with the literature reports that used various other adsorbents for $\mathrm{U}$ removal from aqueous solution. It can be said that FA and TW have moderate adsorption capacities with very high U removal efficiency (99\%). Some synthetic adsorbents (presented in Table 5) had high $\mathrm{U}$ adsorption capacities. However, synthesis will increase the cost of the material and may not be easily available for use to the public in villages.
Table 4 Freundlich and D-R isotherm constants for the adsorption of U on FA and TW

\begin{tabular}{llllllll}
\hline Adsorbent & \multicolumn{2}{l}{ Freundlich isotherm } & & \multicolumn{2}{l}{ D-R isotherm } \\
\cline { 2 - 3 } & $R^{2}$ & $K_{\mathrm{f}}(\mathrm{mg} / \mathrm{g})$ & $n$ & & $R^{2}$ & $q_{\mathrm{m}}(\mathrm{mg} / \mathrm{g})$ & $E(\mathrm{~kJ} / \mathrm{mol})$ \\
\hline FA & 0.94 & 13.80 & 1.19 & & 0.89 & 0.43 & 5.28 \\
TW & 0.97 & 3.28 & 0.77 & & 0.93 & 0.34 & 4.27 \\
\hline
\end{tabular}

Table 5 Comparison of maximum adsorption capacity reported in the present study with the literature reported values

\begin{tabular}{lll}
\hline Adsorbent material & $\begin{array}{l}\text { Maximum adsorption } \\
\text { Capacity for U (mg/g) }\end{array}$ & References \\
\hline Amidoximated hydrogels & 564.0 & Pekel and Güven (2003) \\
$\mathrm{SiO}_{2}$ nanotubes (SNTs) & 250.0 & Tripathi et al. (2018) \\
Rice straw-based carbon & 100.0 & Yakout and Abdeltawab (2015) \\
Mesoporous silica & 58.4 & Stamberg et al. (2003) \\
Cross linked chitosan & 49.1 & Wang et al. (2009) \\
Reduced grapheme sheets & 47 & Li et al. (2012) \\
MX-80 bentonite & 37.4 & Ren et al. (2009) \\
Activated carbon & 28.3 & Mellah et al. (2006) \\
Maghemite NPs & 20.3 & Etale et al. (2016) \\
Diarylazobisphenol modified carbon & 18.7 & Starvin and Rao (2004) \\
Magnetite NPs & 5.0 & Das et al. (2010) \\
Silicon oxide nanoparticles & 2.9 & Wu et al. (2016) \\
FA & $13.8^{\mathrm{a}}$ & Present study \\
TW & $3.3^{\mathrm{a}}$ & Present study \\
\hline
\end{tabular}

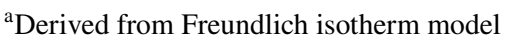




\section{Effect of co-existing cations on $\mathrm{U}$ adsorption}

From results (shown in Fig. 7), it can be observed that, with the increase in solution concentration of $\mathrm{Ca}^{2+}, \mathrm{Mg}^{2+}$ and $\mathrm{Fe}^{3+}$, the $\mathrm{U}$ remained in the supernatant solution also increases (i.e., decrease in adsorption). This indicates that these metal ions are competing with $\mathrm{UO}_{2}{ }^{2+}$ for adsorption sites causing interference. Among three major ions $\left(\mathrm{Ca}^{2+}, \mathrm{Mg}^{2+}\right.$ and $\left.\mathrm{Fe}^{3+}\right)$ studied, the highest interference was observed from $\mathrm{Ca}^{2+}$ followed by $\mathrm{Mg}^{2+}$ and $\mathrm{Fe}^{3+}$ on both the adsorbents. The interference effect is more in the case of TW as compared to FA material.

In the case of FA, U removal percentage was dropped from $99 \%$ (without ion's interference) to $97 \%$ and $97.6 \%$ (with ion's interference), whereas for TW, the percentage removal was dropped from $97 \%$ to $92.5 \%$ and $96.9 \%$ at the highest tested concentrations (400 mg/L) of $\mathrm{Ca}^{2+}$ and $\mathrm{Mg}^{2+}$, respectively. Negligible interference was observed from $\mathrm{Fe}^{3+}$ for $\mathrm{U}$ adsorption on both the adsorbents at all tested $\mathrm{Fe}^{3+}$ concentrations. The $\mathrm{U}$ concentration remained in the solution was found to be within the WHO limit up to the concentration levels of $20 \mathrm{mg} / \mathrm{L}, 200 \mathrm{mg} / \mathrm{L}$ and $200 \mathrm{mg} / \mathrm{L}$ for $\mathrm{Fe}^{3+}, \mathrm{Mg}^{2+}$ and $\mathrm{Ca}^{2+}$, indicates less interference from these cations at the mentioned concentration levels. Whereas for $\mathrm{TW}, \mathrm{U}$ remained in solution was observed to be above the WHO limits for all tested cation concentration levels.

\section{Microstructure of adsorbents}

From adsorption isotherm study, it was understood that $\mathrm{U}$ adsorption on both FA and TW is physical in nature. Hence, surface characterization was carried out on the adsorbents

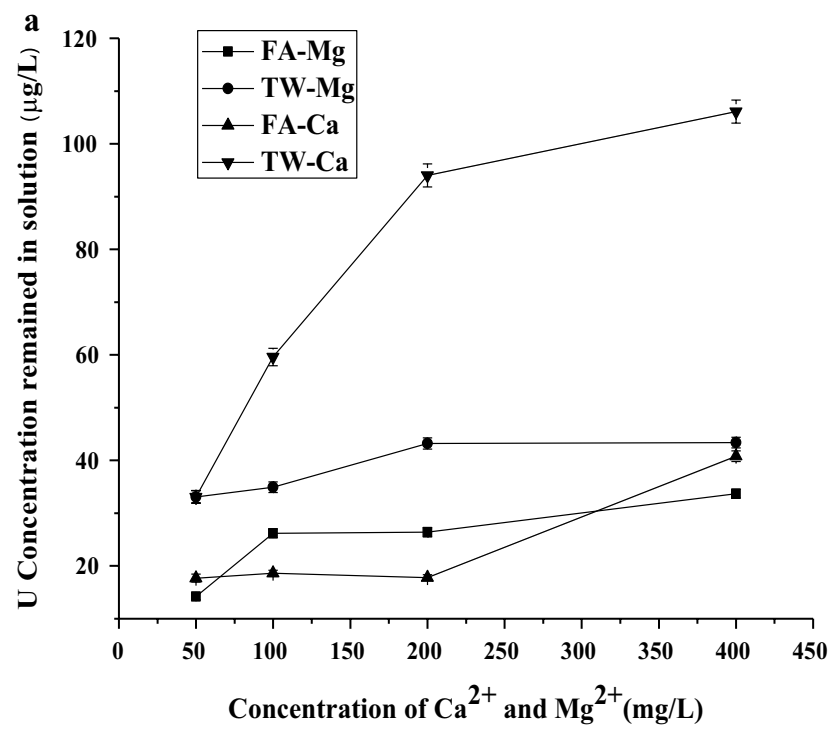

using SEM. The SEM image (Fig. 8) shows that the FA is a heterogeneous material which consists of particles of different sizes and shapes. From Fig. 8, it is clear that the FA finer particles are mostly spherical in nature. But, the larger size particles are irregular in shape and have higher porosity, which enhances the $U$ sorption due to the increase in surface area. Also, FA contains cenospheres (Hanif et al. 2017) which are spherical hollow alumino-silicate particles. The non-spherical cenospheres offer even more surface (inner and outer) area for adsorption leading to higher $\mathrm{U}$ adsorption in FA. Whereas, TW has more irregular-shaped particles and are porous. Also, TW particles are coarse in nature (low surface area) as compared to FA particles, which might be the reason for lower $U$ adsorption on TW than on FA.

The FA and TW are also analyzed to get the information on the major functional groups attached to the surface of adsorbents. Results presented in Fig. 9 suggest that there are various surface functional groups on the adsorbents. By comparing the observed frequencies with available literature, peak in the region (for Fig. 9a) of $1070 \mathrm{~cm}^{-1}$ may be due to $\mathrm{Si}-\mathrm{O}-\mathrm{Si}$ asymmetric stretching vibration (Katara et al. 2013) or $\mathrm{S}=\mathrm{O}$ stretching vibration, whereas peak at $876 \mathrm{~cm}^{-1}$ may be attributed to $\mathrm{C}-\mathrm{O}$ or $\mathrm{C}-\mathrm{H}$ bending. The frequencies observed at $786 \mathrm{~cm}^{-1}$ may be due to $\mathrm{Si}-\mathrm{O}$ symmetrical stretching vibrations (Hlavay et al. 1978). The peaks in the region of $536-523 \mathrm{~cm}^{-1}$ can be due to $\mathrm{Si}-\mathrm{O}-\mathrm{Al}$ stretching vibration (Manoharan et al. 2012). In Fig. 9b, the peak at $3219 \mathrm{~cm}^{-1}$ is due to the presence of $\mathrm{O}-\mathrm{H}$ groups, whereas peak at $2891 \mathrm{~cm}^{-1}$ can be attributed to $\mathrm{C}-\mathrm{H}$ stretching vibrations. Furthermore, peaks at $1592 \mathrm{~cm}^{-1}$ and $1219 \mathrm{~cm}^{-1}$ may be attributed to the $\mathrm{N}-\mathrm{H}$ bending vibrations and $\mathrm{C}-\mathrm{O}$ stretching of epoxy group (Moosa and Jaafar 2017). Peaks

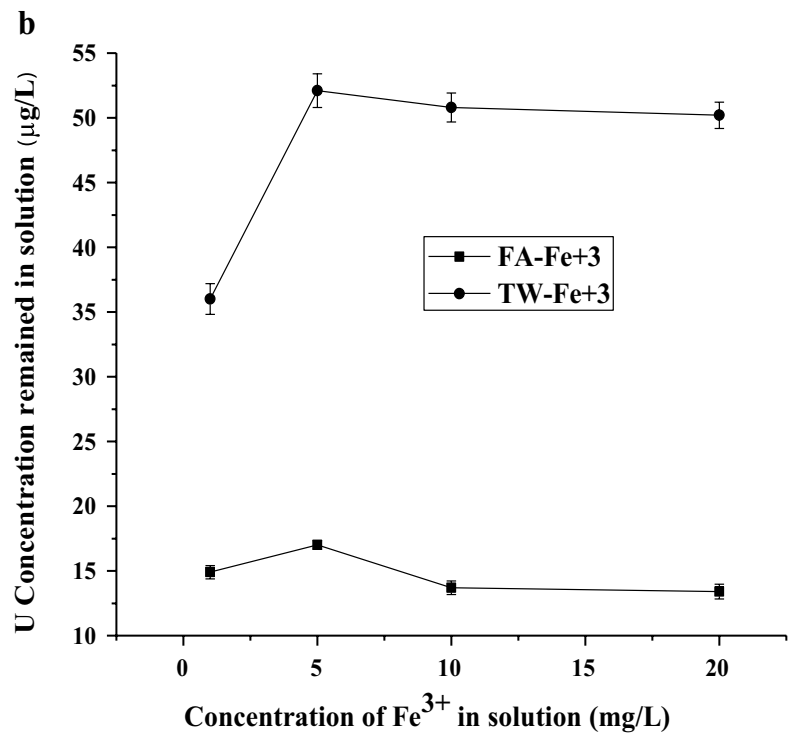

Fig. 7 Effect of co-existing cations $\mathbf{a} \mathrm{Ca}^{2+}$ and $\mathrm{Mg}^{2+} \mathbf{b ~ F e}{ }^{3+}$ on $\mathrm{U}$ adsorption at initial $\mathrm{U}$ concentration of $1415 \mu \mathrm{g} / \mathrm{L}$ 
Fig. 8 SEM images of FA and TW

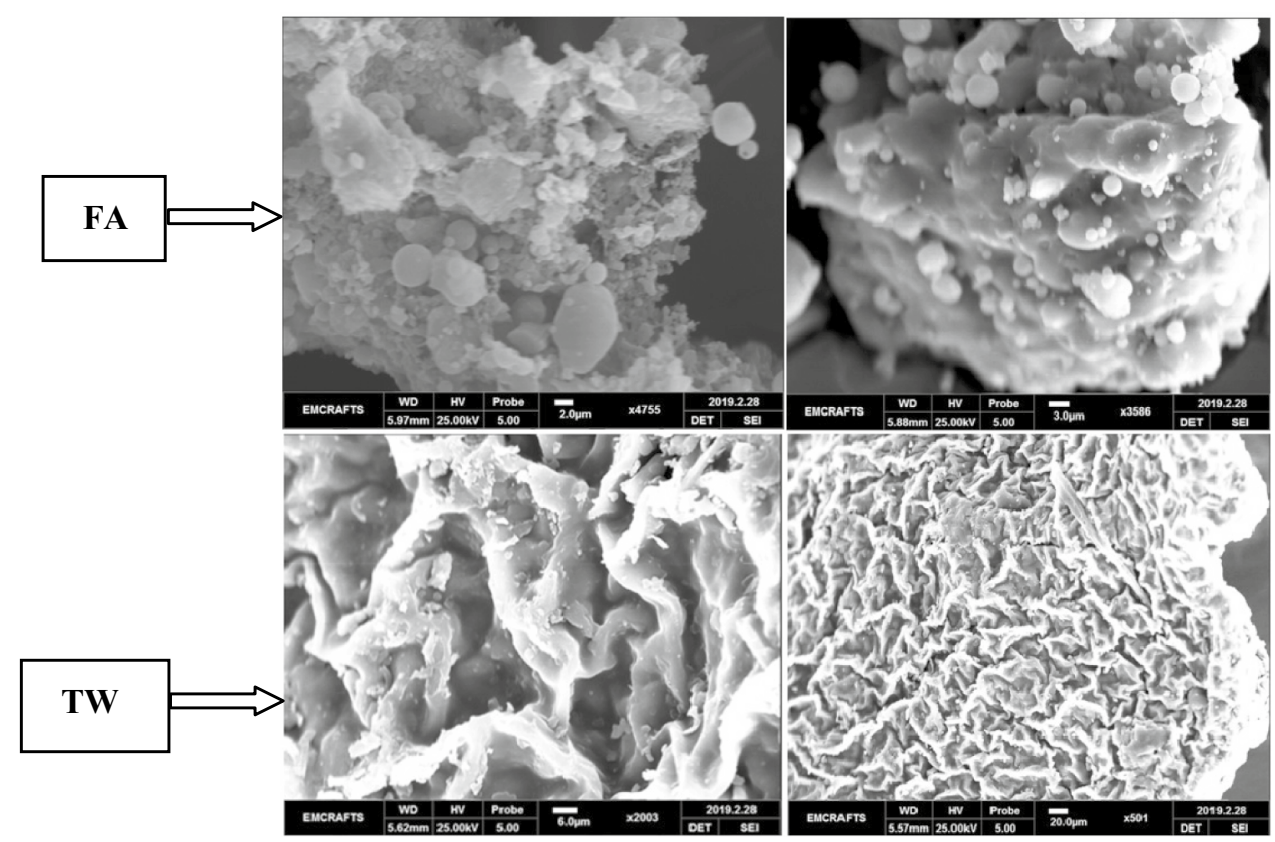

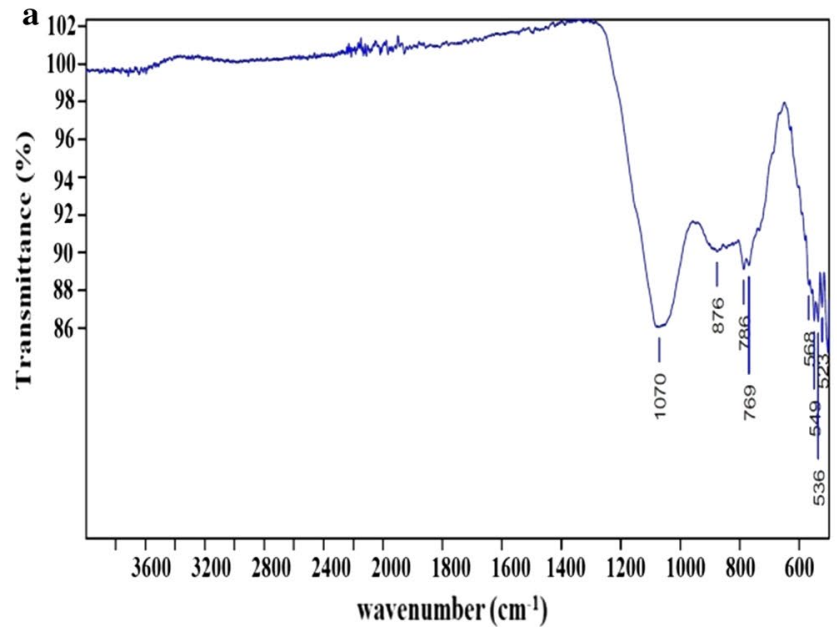

Fig. 9 FTIR spectrum of $\mathbf{a}$ FA and $\mathbf{b}$ TW

in the range of $900-700 \mathrm{~cm}^{-1}$ represent the $\mathrm{C}-\mathrm{H}$ bending vibrations. However, the adsorption being physical in nature, these functional groups might have played a minor role in $\mathrm{U}$ adsorption on FA and TW.

\section{Application of adsorbents for $\mathrm{U}$ removal from spiked real groundwater samples}

To see the reproducibility of above results on real groundwater samples, three different groundwater samples were collected. The collected samples were filtered and spiked with known U concentration $(267 \mu \mathrm{g} / \mathrm{L})$. One gram of TW and FA was added to the spiked solutions separately, and then, the

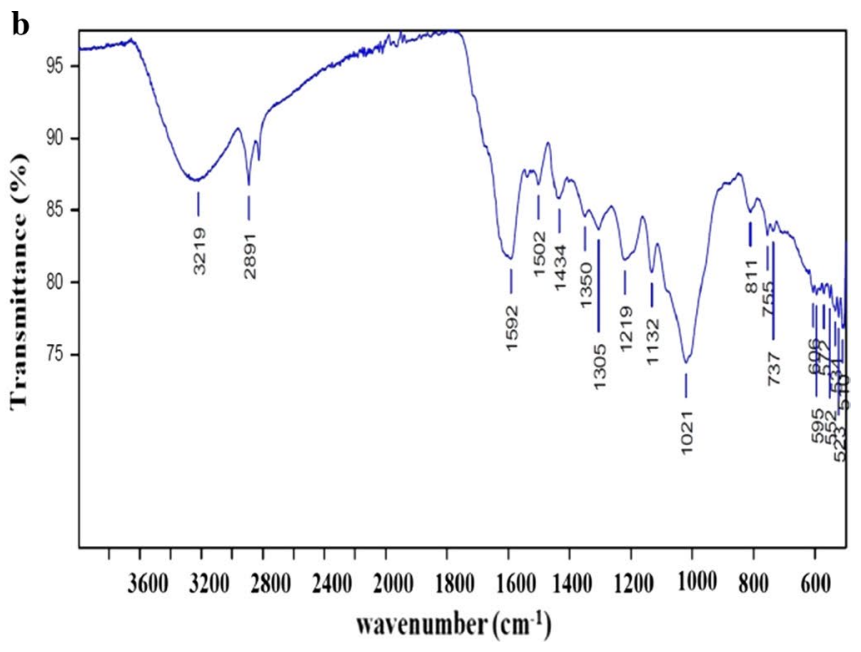

mixture is adjusted for $\mathrm{pH} 6$ and shaken for equilibrium time period. After that, the supernatant is separated by centrifugation and analyzed for $\mathrm{U}$ left out in the solution. The results (shown in Table 6) indicate that the adsorbents are almost equally effective in decontaminating $\mathrm{U}$ from groundwater samples as well.

\section{Conclusions}

The most important conclusion from the study is that the FA can be used to reduce the $\mathrm{U}$ initial concentration to less than the WHO and AERB prescribed limits with $99 \%$ adsorption 
Table 6 Application of adsorbents for $\mathrm{U}$ removal from spiked real groundwater samples

\begin{tabular}{lrlrl}
\hline Sample code & \multicolumn{4}{c}{ U in supernatant solution $(\mu \mathrm{g} / \mathrm{L})$} \\
\cline { 2 - 5 } & \multicolumn{1}{c}{ FA } & \% Removal & \multicolumn{1}{l}{ TW } & \% Removal \\
\hline GW-1 & $4.1 \pm 0.6$ & 98.5 & $10.7 \pm 0.5$ & 96.0 \\
GW-2 & $10.5 \pm 0.8$ & 98.5 & $10.9 \pm 0.6$ & 95.9 \\
GW-4 & $4.0 \pm 0.3$ & 98.5 & $7.9 \pm 0.5$ & 97.0 \\
\hline
\end{tabular}

efficiency at all the examined concentrations (except at $7803.2 \mu \mathrm{g} / \mathrm{L}$ ), whereas TW can be used to decontaminate the U concentration to less than WHO limit for initial U concentration only up to $691 \mu \mathrm{g} / \mathrm{L}$. Adsorption of $\mathrm{U}$ on both the adsorbents followed pseudo-second-order kinetics. The application of intra-particle diffusion model on adsorption data indicates that both the boundary layer diffusion as well as the intra-particle diffusion is responsible for $\mathrm{U}$ adsorption on FA and TW. U adsorption followed multilayer adsorption process and is physical in nature; hence, the adsorbents can be regenerated using mild acids through desorption process for further use. The highest interference from $\mathrm{Ca}^{2+}$ (at $400 \mathrm{mg} / \mathrm{L}$ concentration) was observed for $\mathrm{U}$ adsorption on both the adsorbents, whereas no significant interference was observed from $\mathrm{Fe}^{3+}$ at tested concentrations; the interference effect is more in TW as compared to FA. To conclude, both FA and TW can be used to remove $\mathrm{U}$ from contaminated water. However, application of adsorbents on U spiked real groundwater samples suggests that FA is a better adsorbent as compared to TW for $\mathrm{U}$ removal with very high removal efficiency and moderate adsorption capacity. The present study results also indicate that FA can be used in developing the filters or cartridges to remove $\mathrm{U}$ from contaminated water samples, which may adds to the new ways of using the generated FA in India.

Acknowledgements Authors are thankful to Dr. Mahesh Tiwari for providing SEM facility and all my other colleagues especially Smt. Lalita Uday Nair for her unlimited laboratory support for conducting the experiments.

\section{Compliance with ethical standards}

Conflict of interest On behalf of all authors, the corresponding author states that there is no conflict of interest.

Open Access This article is licensed under a Creative Commons Attribution 4.0 International License, which permits use, sharing, adaptation, distribution and reproduction in any medium or format, as long as you give appropriate credit to the original author(s) and the source, provide a link to the Creative Commons licence, and indicate if changes were made. The images or other third party material in this article are included in the article's Creative Commons licence, unless indicated otherwise in a credit line to the material. If material is not included in the article's Creative Commons licence and your intended use is not permitted by statutory regulation or exceeds the permitted use, you will need to obtain permission directly from the copyright holder. To view a copy of this licence, visit http://creativecommons.org/licenses/by/4.0/.

\section{References}

AERB, DAE, India (2004) Atomic Energy regulatory Board, Department of atomic energy, India, Drinking water specification

Ajmal M, Rao R, Ahmad R, Ahmad J (2000) Adsorption studies on Citrus reticulata (fruit peel of orange) removal and recovery of $\mathrm{Ni}(\mathrm{II})$ from electroplating wastewater. J Hazard Mater 79:117-131

Anirudhan TS, Bringle CD, Rijith S (2010) Removal of uranium(VI) from aqueous solutions and nuclear industry effluents using humic acid-immobilized zirconium-pillared clay. J Environ Radioact 101:267-276

Babel S, Kurniawan TA (2003a) Low cost adsorbents for heavy metals uptake from contaminated water. J Hazard Mater 97(1-3):219-243

Babel S, Kurniawan TA (2003b) Low-cost adsorbents for heavy metals uptake from contaminated water: a review. J Hazard Mater B97:219-243

Babel S, Kurniawan TA (2004) Cr(VI) removal from synthetic wastewater using coconut shell charcoal and commercial activated carbon modified with oxidizing agents and/or chitosan. Chemosphere 54(7):951-967

Bajwa BS, Sanjeev K, Surinder S, Sahoo SK, Tripathi RM (2017) Uranium and other heavy toxic elements distribution in the drinking water samples of SW-Punjab, India. J Radiat Res Appl Sci 10:13-19

Barakat MA (2011) New trends in removing heavy metals from industrial wastewater. Arab J Chem 4:361-377

Bishnoi NR, Bajaj M, Sharma N, Gupta A (2003) Adsorption of Cr(VI) on activated rice husk carbon and activated alumina. Bioresour Technol 91(3):305-307

Calimli MH, Demirbaş Ö, Aygün A, Mehmet A, Nas MS, Khan A, Asiri AM, Şen F (2019) Equilibrium, kinetics and thermodynamics of bovine serum albumin from carbon based materials obtained from food wastes. BioNanoSci 9:692-701. https://doi. org/10.1007/s12668-019-00633-z

Chen G, Shah KJ, Shi L, Chiang PC (2017) Removal of Cd(II) and $\mathrm{Pb}$ (II) ions from aqueous solutions by synthetic mineral adsorbent: performance and mechanisms. Appl Surf Sci 409:296-305

Coyte RM, Jain RC, Srivastava SK, Sharma KC, Khalil A, Ma L, Vengosh A (2018) Large-scale uranium contamination of groundwater resources in India. Environ Sci Technol Lett 5(6):341-347

Davis JA, James RO, Leckie JO (1978) Surface ionization and complexation at the oxide/water interface: I. Computation of electrical double layer properties in simple electrolytes. J Colloid Interface Sci 63:480-499

Demirbaş Ö, Çalımlı MH, Demirkan B, Alma MH, Nas MS, Khan A, Asiri AM, Şen F (2019) Thermodynamics, kinetics, and adsorption properties of biomolecules onto carbon-based materials obtained from food wastes. BioNanoSci 9:672-682. https://doi. org/10.1007/s12668-019-00628-w

Díaz-Cruz MS, Barceló D (2008) Trace organic chemicals contamination in groundwater recharge. Chemosphere 72:333-342

Dimiropoulos V, Katsoyiannis IA, Zouboulis AI, Noli F, Simeonidis K, Mitrakas M (2015) Enhanced U(VI) removal from drinking water by nanostructured binary Fe/Mn oxy-hydroxides. J Water Process Eng 7:227-236

Dimitrova SV (1996) Metal sorption on blast furnace slag. Water Res 30(1):228-232

Domingo JL (1995) Prevention by chelating agents of metal induced development toxicity. Reprod Toxicol 9:105-113

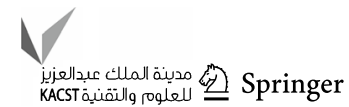


Echevarria G, Sheppard MI, Morel J (2001) Effect of pH on the sorption of uranium in soils. J Environ Radioact 53:257-264

El-Bayaa A, Badawy N, AlKhalik EA (2009) Effect of ionic strength on the adsorption of copper and chromium ions by vermiculite pure clay mineral. J Hazard Mater 170(2):1204-1209

Eltayeb NE, Khan A (2019) Design and preparation of a new and novel nanocomposite with CNTs and its sensor applications. J Mater Res Technol 8(2):2238-2246

Etale A, Tutu H, Drake DC (2016) Application of maghemite nanoparticles as sorbents for the removal of $\mathrm{Cu}(\mathrm{II}), \mathrm{Mn}(\mathrm{II})$ and $\mathrm{U}(\mathrm{VI})$ ions from aqueous solution in acid mine drainage conditions. Appl Water Sci 6:187-197. https://doi.org/10.1007/s13201-014-0217-3

Fu F, Wang Q (2011) Removal of heavy metal ions from wastewaters: a review. J Environ Manag 92:407-418

Gupta KV, Gupta M, Sharma S (2001) Process development for the removal of lead and chromium from aqueous solutions using red mud-an aluminum industry waste. Water Res 35:1125-1134

Hanif A, Lu Z, Li Z (2017) Utilization of fly ash cenosphere as lightweight filler in cement-based composites-a review. Constr Build Mater 144:373-384

He Y, Xiang Y, Zhou Y, Yang Y, Zhang J, Huang H, Shang C, Luo L, Gao J, Tang L (2018) Selenium contamination, consequences and remediation techniques in water and soils: a review. Environ Res 164:288-301

Hlavay J, Jonas K, Elek S, Inczedy J (1978) Characterization of the particle size and the crystallinity of certain minerals by infrared spectrophotometry and other instrumental methods-II. Investigation on quartz and feldspar. Clay Clay Miner 26:139-143

Ho YS, McKay G (1999) Pseudo-second order model for sorption processes. Process Biochem 34:451-465. https://doi. org/10.1016/S0032-9592(98)00112-5

Idrees N, Tabassum B, Abd_Allah EF, Hashem A, Sarah R, Hashim M (2018) Groundwater contamination with cadmium concentrations in some West U.P. Regions, India. Saudi J Biol Sci 25:1365-1368

Inamuddin I, Hussain S, Mohammad A, Khan A (2017) Zinc selective nano-hybrid cation exchanger carboxymethyl cellulose $\mathrm{Zr}$ (IV) tungstate: sol-gel synthesis, physicochemical characterization, and analytical applications. Polym Compos 38(10):2057-2066

Jellali S, Diamantopoulos E, Haddad K, Anane M, Durner W, Mlayah A (2016) Lead removal from aqueous solutions by raw sawdust and magnesium pretreated biochar: experimental investigations and numerical modeling. J Environ Manag 180:439-449

Katara S, Sakshi K, Anita S, Renu H, Ashu R (2013) Surface modification of fly ash by thermal activation: a DR/FTIR study. Int J Pure Appl Chem 3(4):299-307

Khan A, Asiri AM, Parwaz Khan AA, Khan SB (2019a) Electrical conductivity and ion-exchange kinetic studies of polythiophene $\mathrm{Sn}(\mathrm{VI})$ phosphate nanocomposite cation-exchanger. Arab J Chem 12:652-1659

Khan A, Parwaz Khan AA, Hussein MA, Neppolian B, Asiri AM (2019b) Preparation of new and novel wave like poly(2-anisidine) zirconium tungstate nanocomposite: thermal, electrical and ionselective studies. Chin J Chem Eng 27:459-466

Khan A, Parwaz Khana AA, Khan I, Ovesd M, Khane S, Asiri AM, Azum N, Taiba LA, Angaria YMA, Facchetti A (2019c) Facial synthesis of highly active polymer vanadium molybdate nanocomposite: improved thermoelectric and antimicrobial studies. J Phys Chem Solids 131:148-155

Khan MM, Khan A, Asiri AM, Gupta V (2019d) Transport and surface charge density of univalent ion of polyvinyl chloride-based barium tungstate ion-exchange composite membrane for industrial separation of waste water. J Ind Text 49(5):584-596. https://doi. org/10.1177/1528083718791344

Khandaker S, Toyohara Y, Kamida S, Kuba T (2018) Effective removal of cesium from wastewater solutions using an innovative low-cost adsorbent developed from sewage sludge molten slag. J Environ Manag 222:304-315

Li Z, Chen F, Yuan L, Liu Y, Zhao Y, Chai Z, Shi W (2012) Uranium(VI) adsorption on graphene oxide nanosheets from aqueous solutions. Chem Eng J 210:539-546. https://doi.org/10.1016/j. cej.2012.09.030

Maity S, Mishra S, Bhalke S, Pandit GG, Puranik VD, Kushwaha HS (2011) Estimation of distribution coefficient of polonium in geological matrices around uranium mining site. J Radioanal Nucl Chem 290:75-79

Maity S, Mishra S, Pandit GG (2013) Estimation of distribution coefficient of uranium around a uranium mining site. J Radioanal Nucl Chem 295:1581-1588. https://doi.org/10.1007/s1096 7-012-2159-2

Manoharan CP, Sutharsan S, Dhanapandian R, Venkatachalapathy R (2012) Spectroscopic and thermal analysis of red clay for industrial applications from Tamilnadu, India. J Mol Struct 1027:99-103

Mellah A, Chegrouche S, Barkat M (2006) The removal of uranium(VI) from aqueous solutions onto activated carbon: kinetic and thermodynamic investigations. J Colloid Interface Sci 296:434-441

Mishra PC, Patel RK (2009) Removal of lead and zinc ions from water by low cost adsorbents. J Hazard Mater 168:319-325

Mohan D, Pittman CU Jr (2006) Activated carbons and low cost adsorbents for remediation of tri- and hexavalent chromium from water. J Hazard Mater B137:762-811

Montes-Atenasa G, Schroeder SLM (2015) Sustainable natural adsorbents for heavy metal removal from wastewater: lead sorption on pine bark (Pinus radiata D. Don). Surf Interface Anal 47:996-1000

Moosa AA, Jaafar JN (2017) Green reduction of graphene oxide using tea leaves extract with applications to lead ions removal from water. Nanosci Nanotechnol 7(2):38-47. https://doi.org/10.5923/j. nn.20170702.03

Mustapha S, Shuaib DT, Ndamitso MM, Etsuyankpa MB, Sumaila A, Mohammed UM, Nasirudeen MB (2019) Adsorption isotherm, kinetic and thermodynamic studies for the removal of $\mathrm{Pb}(\mathrm{II})$, $\mathrm{Cd}(\mathrm{II}), \mathrm{Zn}(\mathrm{II})$ and $\mathrm{Cu}(\mathrm{II})$ ions from aqueous solutions using Albizia lebbeck pods. Appl Water Sci 9:142. https://doi.org/10.1007/ s13201-019-1021-x

Namasivayam C, Yamuna RT (1995) Adsorption of direct red 12 B by biogas residual slurry: equilibrium and rate processes. Environ Pollut 89:1-7

Onal Y, Akmil-Bas C, Sarıcı-Ozdemir C, Erdogan S (2007) Textural development of sugar beet bagasse activated with $\mathrm{ZnCl}_{2}$. J Hazard Mater 142:138-143

Pang H, Diao Z, Wang X, Ma Y, Yu S, Zhu H, Chen Z, Hu B, Chen J, Wang X (2019) Adsorptive and reductive removal of U(VI) by Dictyophora indusiate-derived biochar supported sulfide NZVI from wastewater. Chem Eng J 366:368-377

Pant D, Keesari T, Sharma D, Rishi M, Singh G, Jaryal A, Sinha UK, Dash A, Tripathi RM (2017) Study on uranium contamination in groundwater of Faridkot and Muktsar districts of Punjab using stable isotopes of water. J Radioanal Nucl Chem 313:635-639

Pekel N, Güven O (2003) Separation of uranyl ions with amidoximated poly(acrylonitrile/ $N$-vinylimidazole) complexing sorbents. Colloids Surf A Physicochem Eng Asp 212:155-161

Pietrelli L, Ippolito NM, Ferro S, Dovì VG, Vocciante M (2019) Removal of Mn and As from drinking water by red mud and pyrolusite. J Environ Manag 237:526-533

Qadeer R, Akhtar S (2005) Study of lead ion adsorption of active carbon. Turk J Chem 29:95-99

Ren X, Wang S, Yang S, Li J (2009) Influence of contact time, pH, soil humic/fulvic acids, ionic strength and temperature on sorption of U(VI) onto MX-80 bentonite. J Radioanal Nucl Chem 283:253-259. https://doi.org/10.1007/s10967-009-0323-0 
Roy P, Mondal NK, Bhattacharya S, Das B, Das K (2013) Removal of arsenic(III) and arsenic(V) on chemically modified low-cost adsorbent: batch and column operations. Appl Water Sci 3:293309. https://doi.org/10.1007/s13201-013-0082-5

Sahoo PK, Tripathy S, Panigrahi MK, Equeenuddin SM (2013) Evaluation of the use of an alkali modified fly ash as a potential adsorbent for the removal of metals from acid mine drainage. Appl Water Sci 3:567-576. https://doi.org/10.1007/s13201-013-0113-2

Sharma T, Sharma A, Kaur I, Mahajan RK, Litoria PK, Sahoo SK, Bajwa BS (2019) Uranium distribution in groundwater and assessment of age dependent radiation dose in Amritsar, Gurdaspur and Pathankot districts of Punjab, India. Chemosphere 219:607-616

Silva RJ, Nitsche H (1995) Actinide environmental chemistry. Radiochim Acta 70(71):377-396

Singh L, Kumar R, Kumar S, Bajwa BS, Singh S (2013) Health risk assessments due to uranium contamination of drinking water in Bathinda region, Punjab state, India. Radioprotection 48(2):191-202

Štamberg K, Venkatesan KA, Vasudeva Rao PR (2003) Surface complexation modeling of uranyl ion sorption on mesoporous silica. Colloids Surf A Physicochem Eng Asp 221:149-162

Starvin AM, Rao TP (2004) Solid phase extractive preconcentration of uranium (VI) onto diarylazobisphenol modified activated carbon. Talanta 63:225-232

Tripathi A, Ranjan MR (2015) Heavy metal removal from wastewater using low cost adsorbents. J Bioremed Biodeg 6:315-319

Tripathi S, Roy A, Nair S, Durani S, Bose R (2018) Removal of U(VI) from aqueous solution by adsorption onto synthesized silica and zinc silicate nanotubes: equilibrium and kinetic aspects with application to real samples. Environ Nanotechnol Monit Manag 10:127-139

Virk HS (2017) A crisis situation due to uranium and heavy metal contamination of ground waters in Punjab state, India: a preliminary report. Res Rev J Toxicol 7(2):6-11

Wang Y-H, Lin S-H, Juang R-S (2003) Removal of heavy metal ions from aqueous solutions using various low-cost adsorbents. J Hazard Mater B102:291-302

Wang G, Liu J, Wang X, Xie Z, Deng N (2009) Adsorption of uranium(VI) from aqueous solution onto cross-linked chitosan. J Hazard Mater 168:1053-1058

Weber WJ Jr, Morris JC (1963) Kinetics of adsorption on carbon from solution. J Sanit Eng ASCE 89:31-59

WHO (2011) Guidelines for drinking water quality, vol 1, 4th edn. World Health Organization, Geneva

Yakout SM, Abdeltawab AA (2015) Adsorption of uranium in the presence of different ions, humic acid and effect of thorium on uranium adsorption by activated carbon. Desalin Water Treat 55:2209-2220

Zyoud AH, Zubi A, Zyoud SH, Hilal MH, Zyoud S, Qamhieh N, Hajamohideen AR, Hilal HS (2019) Kaolin-supported ZnO nanoparticle catalysts in self-sensitized tetracycline photodegradation: zero-point charge and pH effects. Appl Clay Sci 182:105294

Publisher's Note Springer Nature remains neutral with regard to jurisdictional claims in published maps and institutional affiliations. 